\title{
Incorporating Anglo-American Reorganization Provisions in Bankruptcy Law: A 10-year Lesson From Thailand*
}

\author{
Supruet Thavornyutikarn, Natthinee Sereechettapong \\ Thammasat University, Bangkok, Thailand
}

\begin{abstract}
This paper examines the appropriateness of the adoption of Anglo-American type of reorganization provisions into national bankruptcy law using Thailand as a sample. It argues that such adoption shall be cautious. Since Thailand started to accommodate such provisions, reorganization, apparently, has limited usefulness-benefitting only large-scale debtors because it does not fit with the nature of Thai business culture, i.e., the borrowing-lending relationship and less-than-arm's length business connections. On average, only every one in 200 bankruptcy cases employs reorganization; the rest goes for liquidation but the average outstanding debt in reorganization is over 30 times higher than liquidation. Interestingly, the adjudication rate of reorganization is faster than those of liquidation. Debtors' strategic use of the law and the procedural bias are suspected. Debt restructuring led by the central bank in cooperation with commercial banks, instead, is overwhelmingly more successful, equally efficient, and effective because any ailing firm can renegotiate its borrowing contract rather easily in the low transaction cost environment. Debt restructuring outperformed reorganization roughly 800 and two times in terms of cases and debt amount respectively. Thus, the adoption of non-indigenous provisions shall be made prudently. This argument applies towards the standardization of insolvency legislation. Standardizing bankruptcy procedures shall be made carefully and national economic conditions including local business nature and uniqueness are worth examined before any enactment or amendment. Otherwise, benefits of international trade and investment would be achieved at the expense of economic efficiency.
\end{abstract}

Keywords: reorganization, bankruptcy, insolvency, Thailand, standardization of law, debt restructuring

\section{Introduction}

The Asian Financial Crisis in 1997, and its later contagious effect on the global economy, prompted Thailand to amend many business-related laws in order to cope with economic adversaries. One of them was bankruptcy legislation which has been amended in 1999 to incorporate reorganization provisions allowing a corporate debtor to remain in business given creditors' consent as an option to liquidation.

Reorganization provisions are featured in Anglo-American legal practices such as the famous US Chapter 11 in US Bankruptcy Code and the Administration in UK Insolvency Act of 1986. Many countries adopt this

\footnotetext{
* This paper received the funding from Faculty of Economics, Thammasat University, Bangkok, Thailand. Supruet Thavornyutikarn, Ph.D., Lecturer, Faculty of Economics, Thammasat University.

Natthinee Sereechettapong, Barrister-at-Law, Graduate student of TITLE (Thammasat International Trade Law and Economics) Program, Thammasat University. Correspondence concerning this article should be addressed to Supruet Thavornyutikarn, Faculty of Economics, Thammasat University, 2 Prachan Road, Bangkok, 10200, Thailand. E-mail: supruet@econ.tu.ac.th.
} 
type of provisions while others remain to their liquidation-based bankruptcy. Reorganization is available only for corporate debtors, not for personal debtors. The debtor in this paper refers to the corporate debtor.

This paper wants to review, in the context of Thailand, whether the adoption of reorganization is appropriate. In other words, is it economically efficient for Thailand to use this proceeding? If not, reorganization is not the answer to bankruptcy universally and the attempt of United Nations Commission on International Trade Law (UNCITRAL) to encourage the harmonization of insolvency laws and the facilitation of cross-border insolvency are plausibly disagreeable. Therefore, variation of several bankruptcy proceedings must exist across countries depending on their economic fundamentals.

The paper is organized in five sections. After the introduction, some essential basics on bankruptcy from economic perspective are discussed. Then, evidences of Thailand's insolvency legislation and private workouts are illustrated. UNCITRAL's initiatives are briefly examined and followed by implications from Thailand's perspective. This paper concludes with recommendations.

\section{Basics on Bankruptcy}

Essentially, bankruptcy is one of many important components in a borrowing-lending relationship. It is a legal procedure which is usually implemented when all other options have depleted after the debtor's asset is insufficient to service the creditors' claims. Bankruptcy is not a stand-alone process but a sequel to many other attempts after the event of debtor's insolvency. To analyze bankruptcy legislation, it is vital to consider it in the context of the borrowing-lending relationship in general. Considering only the law itself would lead to the misperception and may induce much undesirable and unintentional behavior of creditors and debtor.

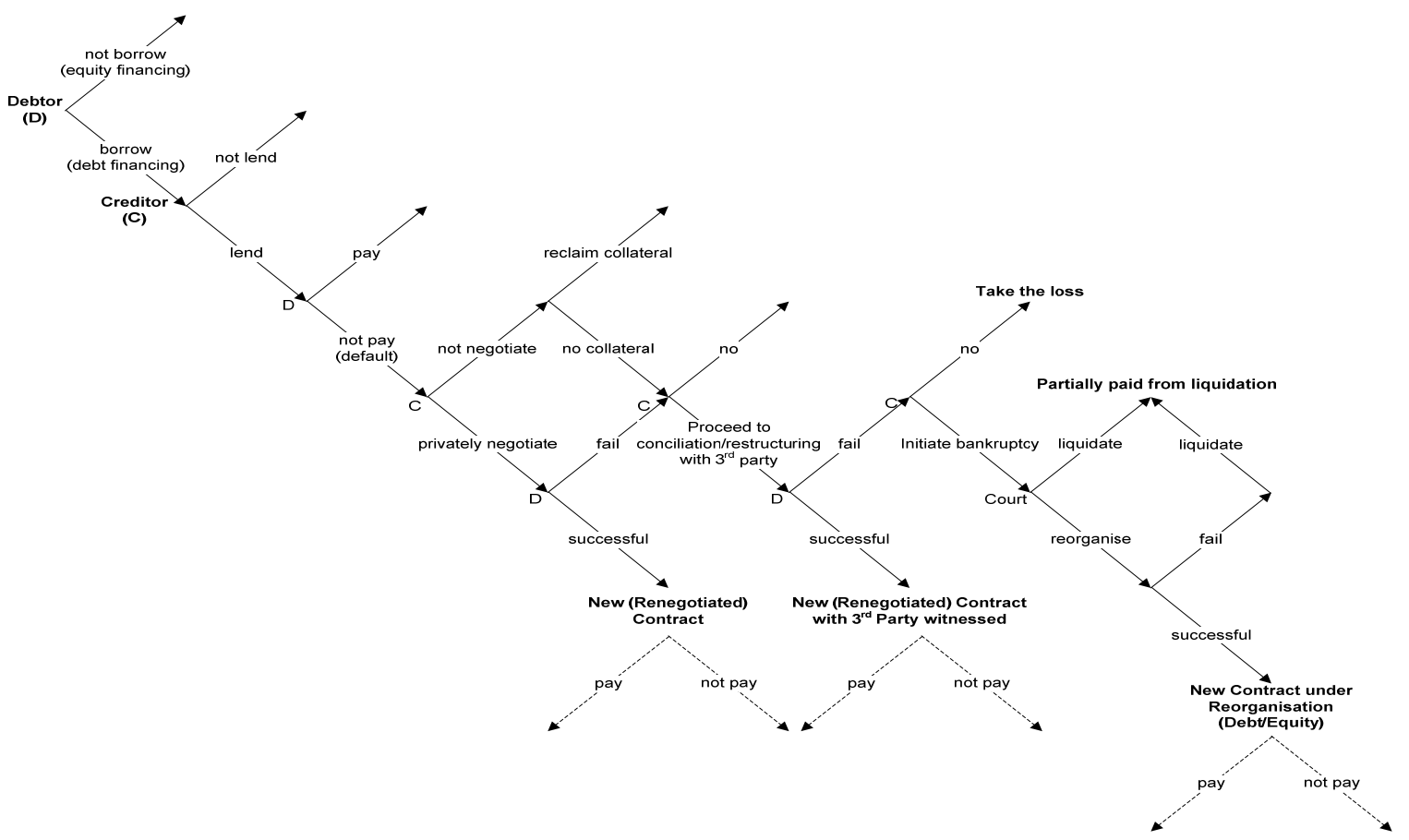

Figure 1. Simplified decision tree of borrowing-lending relationship including bankruptcy with reorganization

The nature of borrowing-lending relationship is sequential and, many times, recursive. Figure 1 illustrates this in the form of decision tree. Apparently, bankruptcy is just one branch of possible alternatives that creditors 
and/or debtor choose. Bankruptcy is optional, not mandatory. Before reaching the bankruptcy procedure, many other procedures have been tried.

\section{Insolvency and Bankruptcy in Economics Perspectives}

Insolvency is a circumstance whereby the amount of debt owed to creditors exceed the assets owned by the debtor. Subsequently, full repayment of all debts is impossible. Since all debts are not due at the same time, some creditors are in the advantageous position to have their debts fully repaid at the expense of other creditors (which have to bear the loss transferred from the debtor). The debtor's default is a tell-tale of insolvency, however, it may be used strategically to induce renegotiation with creditors.

Without the original borrowing contract, there would be no insolvency. In other words, the borrowing-lending relationship or contract is a prerequisite of insolvency. More importantly, more than one of such relationship is a necessary condition for insolvency.

Since the debt contract involves many periods, uncertainty, thus, plays a significant role. Creditors bear the risk of debtor's moral hazard. The debtor, in the mean time, bears the business risk. When the situation changed and the debtor is insolvent, there is an opportunity for the debtor to renegotiate with creditors for plausible solution. For a single creditor, it is straightforward: If the creditor is not satisfied, she would take over the debtor's asset, otherwise, the original contract would be replaced by the renegotiated new contract.

However, some factors that may prevent such renegotiation: number of creditors, amount of loan taken from each creditor, debtor's business outlook, and the possibility of further default. These factors influence transaction cost of renegotiation. When the transaction cost is sufficiently low, renegotiation would eventually give the economically most efficient outcome (Coase, 1960). Unfortunately, the level of transaction costs within each relationship cannot be ascertained. A debtor, for instance, with more creditors, ceteris paribus, would face more difficulties trying to convince diverse creditors than another debtor with fewer creditors. Even they had agreed on renegotiated terms, there is no guarantee against future debtor's default. This heightens transaction costs further. By backward induction, creditors may not be willing to renegotiate from the outset.

Therefore, bankruptcy is created to overcome these problems. It accelerates all debts with different maturities to the present and provides the protection for debtor's assets against any claim using usual legal means (the "stay"). The faith of the debtor is being decided by creditors' voices which are determined by the proportional claims over the debtor's assets (or pro rata or pari passu basis). The debtor could be liquidated or reorganized depending on its economic valuation. Under liquidation or piece-meal liquidation, debtor's assets are sold on a piece-meal fashion, usually through highest-bidder auction; cash earnings (or realization) from the sale will be distributed to all creditors according to the predetermined classification. The debtor firm could be sold as a whole which is called going-concern. Meanwhile, reorganization provides the possibility for the debtor to continue through organizational and/or managerial restructuring to improve its efficiency.

It is vital for bankruptcy legislation to direct the debtor's assets to the highest valuation. Such valuation is based on the creditors' perspective towards the debtor. With low transaction cost, creditors' valuation of the debtor's assets would be close to the real economic value. But when the transaction costs are high-particularly, when there are many creditors, creditors' valuation is diverse. Each creditor does not care what the real value of the firm as a whole is as long as they are paid. The mechanism design of bankruptcy legislation shall concern about this discrepancy.

It is worth noting that bankruptcy is one of all available alternatives to solve insolvency (see Figure 1). 
Principally, bankruptcy is a mechanism for debt renegotiation with the court acting as an umpire. Debt renegotiation could be done through various other mechanisms.

\section{Alternatives for Debt Renegotiation}

There are many venues for debt renegotiation. Certainly, the original borrowing-lending relationship determines what alternative is preferred. Economically speaking, they would select the one with the lowest expected cost. However, the cost and the outcome of each option cannot be ascertained from the outset. They normally proceed gradually from the least cost one to the costlier. Meanwhile, their net benefits from early settlement decline overtime and more complex proceedings. Generally, these alternatives can be categorized into two according to their legal binding force.

Non-binding alternatives. For non-binding alternatives, the debtor settles with creditors privately for whatever solution they had reached — known as private workout. The debtor firm may cease to exist or may continue depending on the agreement. Conditions for such solution are information symmetry, especially the value of the debtor firm is aligned and mutually perceived by all parties; the transaction cost for negotiation is sufficiently low; creditors are certain with their entitlements and the debtor will be abided by the agreement even without any legal enforcement (including no debtor's shirking in the future). If either party does not follow this agreement, there is no specific legal consequence except their a priori rights from the initial contract.

Legal-bounded alternatives. When non-binding attempts are unsuccessful, legally-binding alternatives are still available. They may decide to draft the new contract to amend the original debt contract (usually known as compromise contract/agreement or contract of composition) which effectively replaces the rights, duties, and entitlements of the original one with the newly negotiated one. Bankruptcy legislation in many countries legally recognizes and endorses this kind of private agreement (such as UK Administrative Receivership led by the bank (Armour \& Frisby, 2001)). However, the debtor may strategically negotiate with some creditors and leaving other creditors vulnerable to this new agreement. In this case, the formal bankruptcy is required to prevent such debtor's strategic and opportunistic behavior.

Noting that at this stage the transaction cost is presumably high and the debtor's and creditors' valuation of the firm are misaligned. Normally, these approaches introduce the third party to be a mediator or conciliator. This third party shall have some information of the debtor to facilitate the solution to insolvency. It could be financial institutions who know financial conditions of debtor and creditors or, in the most extreme case, the court using the formal bankruptcy procedure.

Non-bankruptcy procedures may fail to recognize all creditors' entitlement. Bankruptcy is publicly known and all creditors shall be called in to claim their rights. This prevents creditors being taken advantage of either by the debtor or other creditors. Under bankruptcy, there are two orientations: liquidation- and reorganization-orientations as discussed earlier. In some countries, bankruptcy is solely liquidation whilst in some others incorporate the possibility of reorganization into the law. No country has only reorganization.

\section{Efficiency of Insolvency Alternatives}

Choosing among many approaches for insolvency is difficult for both parties. For bankruptcy, the court also has difficulties choosing between liquidation and reorganization (if available). It is always arguable that what is relatively more efficient. But it is impossible to pinpoint which procedure economically superior than another (White, 1998). 
All choices are conditional on how the debtor relates with his creditors originally based on their original borrowing-lending contract (Thavornyutikarn, 2006). Additionally, Stiglitz (2001) asserts the importance of economic fundamentals of each particular country on the optimal balance of different procedures. Economically speaking, all procedures, legally binding and non-binding shall be available to channel the troubled company to its highest valuation, hence, the economic efficiency is achieved. The mechanism design of bankruptcy law shall reflect this concept and utilize the nature of the initial debt contract without focusing solely on legal substances and proceedings. Table 1 summarizes appropriate procedures for insolvency under different conditions between debtor and creditors.

Table 1

Appropriate Procedures for Insolvency Under Different Conditions

\begin{tabular}{|c|c|c|c|}
\hline & \multirow{2}{*}{$\begin{array}{l}\text { Legally } \\
\text { non-binding }\end{array}$} & \multicolumn{2}{|l|}{ Legally binding } \\
\hline & & $\begin{array}{l}\text { Private agreement } \\
\text { w/third party }\end{array}$ & Formal bankruptcy \\
\hline \multicolumn{4}{|l|}{ Before insolvency } \\
\hline $\begin{array}{l}\text { Debtor's asset specificity/non-verifiable } \\
\text { variables/non-market assets (human capital) }\end{array}$ & Low & Low-Medium & High \\
\hline Separation between ownership and control & No-Low & Low-Medium & High \\
\hline Number of creditors & Few & Not many & Many \\
\hline Amount of debt & Not large & Relatively not large & Large \\
\hline Length of contract & Short & Relatively short & Long \\
\hline Diversity of debt proportional to each creditor & Very similar & Similar-Diversified & Highly diversified \\
\hline Repeated relationship between debtor and creditor & $\begin{array}{l}\text { Regularly } \\
\text { repeated }\end{array}$ & Repeated & One-off-irregularly repeated \\
\hline Likelihood of moral hazard & Low & Medium & High \\
\hline Ease of monitoring by creditors & Easy & Easy-Medium & Difficult \\
\hline Legal enforcement of original contract & Yes & No & No \\
\hline \multicolumn{4}{|l|}{ After insolvency } \\
\hline Ease of renegotiation & Easy & Medium & Difficult \\
\hline $\begin{array}{l}\text { Difference between the company's value perceived by the } \\
\text { debtor and creditors }\end{array}$ & Low & Low-Medium & High \\
\hline $\begin{array}{l}\text { Differences of company's value perceived by different } \\
\text { creditors }\end{array}$ & Low & Low-Medium & High \\
\hline $\begin{array}{l}\text { Likelihood of debtor's shirking (moral hazard after } \\
\text { renegotiation) }\end{array}$ & Low & Low-Medium & High \\
\hline Accuracy of market valuation of the company's value & High & Medium-High & Low \\
\hline Value of the company as a whole & $\begin{array}{l}\text { Depending on } \\
\text { negotiation }\end{array}$ & $\begin{array}{l}\text { Depending on } \\
\text { negotiation }\end{array}$ & $\begin{array}{l}\text { Low (Liquidation)/ } \\
\text { High (Reorganization) }\end{array}$ \\
\hline Possibility of future recursive debt contract & $\begin{array}{l}\text { Depending on } \\
\text { negotiation }\end{array}$ & $\begin{array}{l}\text { Depending on } \\
\text { negotiation }\end{array}$ & $\begin{array}{l}\text { Low (Liquidation)/ } \\
\text { High (Reorganization) }\end{array}$ \\
\hline Legal enforcement of renegotiated contract & No & Yes & Yes \\
\hline
\end{tabular}

\section{Thailand's Amendment of Bankruptcy Legislation and Lessons Learned}

This section explains how Thailand amended its bankruptcy legislation to incorporate the reorganization-based procedure and what the empirical results are. There was a private alternative attempt to bankruptcy during the same period which worth considering and comparing.

A 1997 Asian Financial Crisis exerted tremendous pressure on Thailand's economy. Many companies went out of business including 56 financial institutions (IMF, 2000). Thailand was believed to be the origin of this contagion (Kaufman, Krueger, \& Hunter, 1999). Thailand, later, took IMF Program and the reform of 
bankruptcy act was one of many institutional repercussions and legal reforms (IMF, 2000).

An inclusion of reorganization clauses was the highlight of Thailand's bankruptcy reform. Previously, corporate debtor under bankruptcy must be liquidated by court-appointed receiver (absolute receivership).

\section{Evidence of Reorganization in Thailand}

After the amendment of Bankruptcy Act in 1998, many distressed corporate debtors have been through the process of reorganization. Thavornyutikarn (2006) analyzed the empirical evidence on this using a firm-level panel data of 166 companies in various stages of reorganization between 1998 and 2000 and limited dependent variable econometric analyses. The results were the characterization of corporate debtor at each step in reorganization. Table 2 summarizes the characteristics of those firms explained in term of its effects on probabilities being admitted into reorganization and being successfully reorganized respectively.

Table 2

Characteristics of Corporate Debtor Entering to and Exiting From Reorganization in Thailand

\begin{tabular}{lll}
\hline Characteristics & $\begin{array}{l}\text { Probability of entry to } \\
\text { reorganization }\end{array}$ & $\begin{array}{l}\text { Probability of exit from } \\
\text { reorganization }\end{array}$ \\
\hline Asset specificity (total asset/number of employees) & $\mathrm{n} / \mathrm{a}$ & {$[-]$} \\
Amount of debt & + & $\mathrm{n} / \mathrm{a}$ \\
Number of creditors & + & {$[-]$} \\
Proportion of debt owed to financial institution creditors & {$[+]$} & {$[+]$} \\
Proportion of debt owed to trade creditors & + & {$[-]$} \\
Difference between interest expenses and earnings & - & - \\
Proportion of unburdened assets (working capital/total assets) & - & + \\
Operating revenue per employee & $\mathrm{n} / \mathrm{a}$ & + \\
Proportion of operating expenses to total assets & $\mathrm{n} / \mathrm{a}$ & - \\
\hline
\end{tabular}

Notes. [..] indicates the empirical finding contradicts the theoretical conjecture (compare with Table 1); ${ }^{*}$ refers only to successfully reorganized firms; n/a: not applicable. Source: Adapted from Thavornyutikarn (2006).

Thavornyutikarn (2006) discovered some discrepancies in the Thai reorganization as follow. The procedures was inclined towards the debtor with many financial institution creditors which shall not using reorganization but the private workout led by those financial institutions (Eisenberg \& Tagashira, 1996; Hoshi, Kashyap, \& Scharfstein, 1996) or something similar to a privately-appointed (bank-appointed) administrative receivership of the UK (Armour \& Frisby, 2001). This is further discussed below.

Moreover, Thailand's reorganization was against trade creditors which are more affected by debtor's insolvency than financial institution creditors since they have no ability to diversify their risks. ${ }^{1}$ And because they are vital to the continuity of the distressed debtor (Biais \& Gollier, 1997), reorganization would be less likely to be successful if they are less protected (Sautner \& Vladimirov, 2012). Biais and Gollier (1997) also asserted that trade creditors can reduce information asymmetry between the debtor and other creditors. Trade creditors relate with the debtor in a more repeated fashion and sometimes have lower costs of monitoring the debtor (see Table 1). Thus, they are presumably good informants which shall be included in reorganization in helping all creditors to realize the real value of the firm. This is another shortfall of the Thai reorganization provisions.

\footnotetext{
${ }^{1}$ Even in the US, where its Chapter 11 is famous for having inclination towards the debtor. The Bankruptcy Code was revised to provide better protection for trade creditors under Section 546(c) and 503(b)(9) of Bankruptcy Abuse Prevention and Consumer Protection Act (BAPCPA) in 2005.
} 
Asset specificity is another dimension which was not concerned by reorganization. A corporate debtor with higher asset specificity tends to have lower market value for such specific assets and reorganization shall preserve those values. Empirically, the mechanism did the opposite.

A number of creditors worked oppositely at the entry and the exit. It did increase the probability of being accepted into reorganization since the transaction costs could be prohibitively high for any private workout. But it shall not be significant in determining the chance of being successfully reorganized because the procedure must be able to extract some information from the debtor about its real value. This implies information asymmetries had not been alleviated in the process.

After the recent recollection of data, interesting sets of statistics are unveiled. Table 3 shows the petition for reorganization according to the database of the Central Bankruptcy Court. ${ }^{2}$ Table 4 indicates statistics of bankruptcy cases from the Central Bankruptcy Court.

It is apparent that reorganization (see Table 3) were likely to be used by the debtor rather creditors. Within the past decade, debtors filing for reorganization are, on average, 4.48 times higher than creditors. This indicates that the mechanism of reorganization provisions has an inclination towards debtor.

Table 3

Petition for Reorganization, 1999-2012

\begin{tabular}{lcccl}
\hline \multirow{2}{*}{ Year } & \multicolumn{2}{l}{ Reorganization petition filed by } & Total reorganization & Retition \\
\cline { 2 - 5 } & Creditor & Debtor & 5 & 0.67 \\
2000 & 3 & 20 & 29 & 2.22 \\
2001 & 9 & 0 & 2 & n/a (creditor) \\
2002 & 2 & 1 & 1 & n/a (debtor) \\
2003 & 0 & 2 & 2 & n/a (debtor) \\
2004 & 0 & 8 & 8 & n/a (debtor) \\
2005 & 1 & 5 & 6 & 5.00 \\
2006 & 3 & 15 & 18 & 5.00 \\
2007 & 3 & 26 & 29 & 8.67 \\
2008 & 4 & 1 & 5 & 0.25 \\
2009 & n/a & n/a & n/a & n/a \\
2010 & 3 & 28 & 31 & 9.33 \\
2011 & 14 & 17 & 31 & 1.21 \\
$2012^{*}$ & 3 & 24 & 27 & 8 \\
\hline
\end{tabular}

Note. ${ }^{*}$ As of July 2012; Source: Online database, Central Bankruptcy Court.

Statistics from Table 4 seems to confirm this liquidation cases outnumbered reorganization cases by staggering 200 times on average. This denotes the increasingly insignificance of reorganization in term of cases. Noting that, the rate of adjudication in reorganization is higher than in liquidation. It seems to contradict with the general intuition that reorganization is much more difficult to achieve than liquidation. This possibly hints the procedural bias.

Table 5 reveals the amount of debt owed to creditors in liquidation and reorganization. On average, the value of debt in reorganization is 32.23 times higher than in liquidation. This could explain why Thailand was

\footnotetext{
${ }^{2}$ Accuracy of this data cannot be verified because it is the online, unpublished, database retrieved at the terminal computer of the Central Bankruptcy Court.
} 
in need of bankruptcy reform during the crisis. Owning to the fact that not many debtors seeking reorganization, all of them were high-profile cases (extremely high debt) and their failure may inflict substantial damage to the Thai economy. Also, it could explain the bias for debtors (against creditors) inherited in the Thai bankruptcy legislation, especially reorganization.

Table 4

Bankruptcy Cases Between 1999 and 2012

\begin{tabular}{|c|c|c|c|c|c|c|c|}
\hline \multirow{2}{*}{ Year } & \multicolumn{3}{|c|}{ Liquidation } & \multicolumn{3}{|c|}{ Reorganization } & \multirow{2}{*}{$\begin{array}{l}\text { Ratio of liquidation tc } \\
\text { reorganization }\end{array}$} \\
\hline & Outstanding & Adjudicated & $\%$ & Outstanding & Adjudicated & $\%$ & \\
\hline 1999 & 416 & 210 & 50.48 & 25 & 21 & 84.00 & 16.01 \\
\hline 2000 & 1,200 & 928 & 77.33 & 139 & 119 & 85.61 & 8.63 \\
\hline 2001 & 1,845 & 1,159 & 62.82 & 104 & 96 & 92.31 & 17.74 \\
\hline 2002 & 2,592 & 2,026 & 78.16 & 68 & 61 & 89.71 & 38.12 \\
\hline 2003 & 3,944 & 2,321 & 58.85 & 58 & 53 & 91.39 & 68.99 \\
\hline 2004 & 7,306 & 5,061 & 69.27 & 57 & 49 & 85.96 & 128.18 \\
\hline 2005 & 10,266 & 5,524 & 53.81 & 46 & 36 & 78.26 & 223.17 \\
\hline 2006 & 17,986 & 8,789 & 48.87 & 62 & 40 & 64.51 & 290.09 \\
\hline 2007 & 24,577 & 16,046 & 65.29 & 79 & 55 & 69.62 & 311.10 \\
\hline 2008 & 25,301 & 9,978 & 39.44 & 78 & 60 & 76.92 & 324.37 \\
\hline 2009 & 33,848 & 23,975 & 70.83 & 60 & 40 & 66.67 & 564.13 \\
\hline 2010 & 24,129 & 17,586 & 72.88 & 73 & 59 & 80.82 & 330.53 \\
\hline \multirow[t]{2}{*}{$2011^{*}$} & 15,161 & 10,317 & 68.05 & 48 & 37 & 77.08 & 315.85 \\
\hline & & Average & 62.77 & & & 79.90 & \\
\hline
\end{tabular}

Note. $^{*}$ As of November 2011; Source: Central Bankruptcy Court (2012).

Table 5

Amount of Debt in Bankruptcy Cases Between 1999 and 2012

\begin{tabular}{|c|c|c|c|c|c|c|c|}
\hline \multirow[b]{2}{*}{ Year } & \multicolumn{3}{|c|}{ Liquidation } & \multicolumn{3}{|c|}{ Reorganization } & \multirow{2}{*}{$\begin{array}{l}\text { Ratio of average debt } \\
\text { t amount in reorganization } \\
\text { to liquidation }\end{array}$} \\
\hline & $\begin{array}{l}\text { New } \\
\text { cases }\end{array}$ & $\begin{array}{l}\text { Amount of debt } \\
\text { (million Baht) }\end{array}$ & $\begin{array}{l}\begin{array}{l}\text { Average debt amount } \\
\text { (million Baht) }\end{array} \\
\end{array}$ & $\begin{array}{l}\text { New } \\
\text { cases }\end{array}$ & $\begin{array}{l}\text { Amount of debt } \\
\text { (million Baht) }\end{array}$ & $\begin{array}{l}\begin{array}{l}\text { Average debt amount } \\
\text { (million Baht) }\end{array} \\
\end{array}$ & \\
\hline 1999 & 416 & $10,148.74$ & 24.39 & 25 & $153,796.90$ & $6,151.88$ & 252.17 \\
\hline 2000 & 994 & $129,104.16$ & 129.88 & 135 & $672,012.29$ & 4,977.87 & 38.33 \\
\hline 2001 & 1,573 & $628,270.47$ & 399.41 & 84 & $367,349.91$ & 4,373.21 & 10.95 \\
\hline 2002 & 1,906 & $688,251.05$ & 361.10 & 60 & $144,095.24$ & $2,401.59$ & 6.65 \\
\hline 2003 & 3,378 & $94,197.72$ & 27.89 & 51 & $163,557.62$ & $3,207.01$ & 115.01 \\
\hline 2004 & 5,683 & $77,440.99$ & 13.63 & 52 & $167,422.46$ & $3,219.66$ & 236.27 \\
\hline 2005 & 8,021 & $408,754.28$ & 50.96 & 38 & $30,736.38$ & 808.85 & 15.87 \\
\hline 2006 & 13,244 & $174,121.58$ & 13.15 & 52 & $94,974.52$ & $1,826.43$ & 138.92 \\
\hline 2007 & 15,380 & $187,249.21$ & 12.17 & 57 & $178,678.63$ & $3,143.71$ & 257.47 \\
\hline 2008 & 16,770 & $257,650.02$ & 15.36 & 54 & $125,729.90$ & 2,328.31 & 151.55 \\
\hline 2009 & 18,525 & $388,620.03$ & 20.98 & 42 & $61,913.31$ & $1,474.13$ & 70.27 \\
\hline 2010 & 14,256 & $387,754.23$ & 27.20 & 53 & $38,312.14$ & 722.87 & 26.58 \\
\hline \multirow[t]{2}{*}{$2011 *$} & 8,618 & $339,634.78$ & 39.41 & 34 & $67,160.41$ & $1,975.31$ & 50.12 \\
\hline & & Average & 87.35 & & & $2,815.53$ & \\
\hline
\end{tabular}

Note. $^{*}$ As of November 2011; Source: Central Bankruptcy Court (2012).

\section{Private Workout in Thailand}

As mentioned earlier, the insolvency problem is not completed without the consideration of informal approaches and the initial borrowing-lending relationship. This section covers the evidence of private workouts 
in Thailand to compare the performance of reorganization procedure previously investigated.

Since real private workouts are not recorded, there is no information about it. However, studies in Japan by Eisenberg and Tagashira (1996); Hoshi, Kashyap, and Scharfstein (1996) and in the UK by Armour and Frisby (2001) indicated the pivotal role of financial institutions in leading the private workouts for distressed debtors. Thailand shares a very similar financial landscape with these two countries particularly in debt financing. There is limited number of commercial banks and most business debtors are linked with these banks (Akira, 1996; Pongpaichit \& Baker, 1995; Thavornyutikarn, 2006).

Indeed, the Bank of Thailand (BoT) set up the facility called Corporate Debt Restructuring Advisory Committee (CDRAC) in 1998. CDRAC is effectively a parallel mechanism for debt restructuring assisting distressed debtors to be solvent. ${ }^{3}$ Its purpose is to persuade financial institutions who are creditors to continue providing loans to debtor businesses and assisting the debt restructuring process in order to reduce the non-performing loans (NPLs) (Dasri, 2000; Thavornyutikarn, 2006). Agreements under CDRAC are privately negotiated between the troubled firm and its financial institutions in a single, unified group. Successful renegotiation resulted in a new multilateral, legally-bound contract outlining the debt restructuring process. However, under the Thai bankruptcy legislation, this scheme is not recognized as a bankruptcy proceeding but as contractual obligations under the law of contract which would be overruled if the bankruptcy proceeding of the debtor commences.

Empirically, CDRAC was highly successful. Table 6 illustrates the progress of debt restructuring through CDRAC facilities.

Table 6

Debt Restructuring Under BoT's CDRAC Scheme

\begin{tabular}{|c|c|c|c|c|c|c|c|}
\hline \multirow{2}{*}{ Year } & \multicolumn{3}{|c|}{ Cases } & \multicolumn{3}{|c|}{ Amount of debt (million Baht) } & \multirow{2}{*}{$\begin{array}{l}\text { Average debt amount per } \\
\text { case (million Baht) }\end{array}$} \\
\hline & Outstanding & Restructured & $\%$ & Outstanding & Restructured & $\%$ & \\
\hline 1999 & 199,909 & 173,709 & 86.89 & $2,192,608$ & $1,072,095$ & 48.89 & 10.97 \\
\hline 2000 & 608,447 & 532,196 & 83.47 & $2,340,347$ & $1,953,520$ & 87.46 & 3.85 \\
\hline 2001 & 523,430 & 476,137 & 90.96 & $2,570,940$ & $2,429,093$ & 94.48 & 4.91 \\
\hline 2002 & $\mathrm{n} / \mathrm{a}$ & $\mathrm{n} / \mathrm{a}$ & $\mathrm{n} / \mathrm{a}$ & $\mathrm{n} / \mathrm{a}$ & $\mathrm{n} / \mathrm{a}$ & $\mathrm{n} / \mathrm{a}$ & $\mathrm{n} / \mathrm{a}$ \\
\hline 2003 & $\mathrm{n} / \mathrm{a}$ & $\mathrm{n} / \mathrm{a}$ & $\mathrm{n} / \mathrm{a}$ & $\mathrm{n} / \mathrm{a}$ & $\mathrm{n} / \mathrm{a}$ & $\mathrm{n} / \mathrm{a}$ & $\mathrm{n} / \mathrm{a}$ \\
\hline 2004 & 11,705 & 11,441 & 97.75 & $1,499,089$ & $1,497,820$ & 99.92 & 128.07 \\
\hline
\end{tabular}

Note. Data of 2002 and 2003 are not available; Source: CDRAC, Bank of Thailand (1999-2001; 2004).

Note that the amounts of debt undergone CDRAC scheme were always significantly larger than in liquidation and reorganization combined. Notwithstanding, success rates in debt restructuring outperformed adjudication rates of liquidation and reorganization in terms of number of cases and amount of debt. This affirms our conjecture about the nature of borrowing-lending relationships and solutions to insolvency in Thailand. Most cases can be settled outside formal procedures. If private workouts failed, debtors are more likely to be liquidated unless the value of debt is exceptionally high. The per-case average debt is the range of 10-130 million Baht for CDRAC, 15-400 million Baht for liquidation, and 700-6,000 million Baht for reorganization (compare Tables 5 and 6). Liquidation and reorganization shall not be differentiated by the debt value. Both must be accessible for the debtor depending on whichever gives the highest valuation. Reorganization shall not be used to preserve high value debts but to preserve the debtor that worth more active

\footnotetext{
${ }^{3}$ It is called Bangkok Approach, after London Approach where CDRAC mechanism modeled on (Dasri, 2000).
} 
than defunct. Analogously, liquidation shall not be used for the distribution of low value debts but to respect creditors' rights when the debtor is worth more defunct than active.

\section{Comparing Private Workout and Formal Bankruptcy}

Based on the cases and outstanding debt under CDRAC in Table 6, Table 7 compares private workout and formal procedures of bankruptcy in percentage terms.

Table 7

Comparison of Private Workout and Formal Bankruptcy Procedures

\begin{tabular}{|c|c|c|c|c|c|c|}
\hline \multicolumn{7}{|c|}{ Percentage of base line (Outstanding cases and debt amount in CDRAC as a base line) } \\
\hline \multirow{2}{*}{ Year } & \multicolumn{3}{|c|}{$\begin{array}{lc}\text { Cases } \\
\end{array}$} & \multicolumn{3}{|c|}{ Amount of debt } \\
\hline & Liquidation & Reorganization & Combined & Liquidation & Reorganization & Combined \\
\hline 1999 & 0.208 & 0.013 & 0.221 & 0.463 & 7.014 & 7.477 \\
\hline 2000 & 0.163 & 0.022 & 0.186 & 5.516 & 28.714 & 34.231 \\
\hline 2001 & 0.300 & 0.016 & 0.316 & 24.437 & 14.289 & 38.726 \\
\hline 2002 & $\mathrm{n} / \mathrm{a}$ & $\mathrm{n} / \mathrm{a}$ & $\mathrm{n} / \mathrm{a}$ & $\mathrm{n} / \mathrm{a}$ & $\mathrm{n} / \mathrm{a}$ & $\mathrm{n} / \mathrm{a}$ \\
\hline 2003 & $\mathrm{n} / \mathrm{a}$ & $\mathrm{n} / \mathrm{a}$ & $\mathrm{n} / \mathrm{a}$ & $\mathrm{n} / \mathrm{a}$ & $\mathrm{n} / \mathrm{a}$ & $\mathrm{n} / \mathrm{a}$ \\
\hline 2004 & 48.552 & 0.444 & 48.996 & 5.165 & 11.168 & 16.344 \\
\hline
\end{tabular}

Interestingly, more than 40 percent of debtors in reorganization had successfully reached agreements under CDRAC (Thavornyutikarn, 2006). Thus, all figures on reorganization must be discounted by 40 percent, rendering it even less important. Their entry into reorganization was questionable and suspiciously strategic. Also, it posed a threat of forum shopping and, subsequently, undermining borrowing-lending relationships.

In all cases, formal bankruptcy is accounted for less than half of private workout-both in terms of number and outstanding debt. Therefore, formal bankruptcy is, in general, less operative than private workout. Within bankruptcy, liquidation is relatively more active than reorganization in term of cases; while reorganization is relatively more active than liquidation in term of debt value. In the context of Thailand, reorganization is possibly redundant; thus, the adoption of such provisions is economically inefficient. It is too expensive to institutionalize reorganization where most cases could be solved in private workouts.

\section{UNCITRAL on Bankruptcy: Legislative Guide and Model Law on Cross-Border Insolvency}

UNCITRAL aims to modernize and harmonies rules on international business by providing legislative guides and model laws, information dissemination, and technical assistance. Insolvency is one of the covered areas.

\section{On the Legislative Guide}

The Legislative Guide (the Guide) offers guidelines and recommendations on how to draft efficient and effective insolvency legislation and system. Despite the fact that the Guide does not intend to "provide a single set of model solutions" (UNCITRAL, 2005), the UN General Assembly Resolution did believe that the harmonization of insolvency legal framework would be established, international standards of insolvency would be developed, and recommend the Model Law on Cross-Border Insolvency to be implemented. ${ }^{4}$ The findings above disagree with this belief.

\footnotetext{
${ }^{4}$ UN General Assembly Resolution, A/RES/59/40, 16 December, 2004.
} 
Lessons learned from Thailand indicate the impossibility of an internationally harmonized insolvency legal framework since the legislation must be drafted and concern about the nature of borrowing-lending relationship (because it determines how insolvency evolves and be solved) and economic fundamentals which vary from country to country ${ }^{5}$ to attend economic efficiency.

The Guide, however, provides many useful commentaries on key issues and respective recommendations for enactment and/or amendment. ${ }^{6}$

\section{On the Model Law}

Due to the expansion of international trade and investment, insolvency becomes international issues particularly for multinational investors. Incompatibility of bankruptcy procedures creates the barrier for international transactions. UNCITRAL proposed the Model Law on Cross-Border Insolvency for cooperation among legal authorities, improvement of business certainty, and protection of stakeholders' entitlement (UNCITRAL, 2005).

Many works emphasized on how the enactment of the Model Law improves international trade and investment for their respective economies including Rotjanasiributr (2001) for Thailand and Locatelli (2008) for Brazil. The direct adoption, however, shall be warned and differences among national laws are respected. ${ }^{7}$

In the context of Thailand, the Model Law may not be relevant for a couple of reasons. First, most debtors in financial distress are likely to use private workouts compare to formal bankruptcy by large margin. Secondly, foreign companies are strictly regulated and must be explicitly permitted ${ }^{8}$; subsequently, there are not many foreign firms ex ante to be possibly insolvent. Even though the adoption reduces uncertainty internationally, other legal barriers which are more crucial than bankruptcy, still exist in preventing international trade and investment. Lastly, the Thailand's saving-investment gap is wide, even though narrowing (Sussangkarn \& Nikomborirak, 2010), implying not many Thai investors abroad and their difficulty from insolvency of their debtors is contained.

The compatibility of insolvency legislation across nations is undeniably beneficial and encourages international transactions, but at the expense of less efficient bankruptcy procedures that are not fully tailored for national exclusivity. Moreover, there are many more laws in Thailand that shall be reformed to achieve the same objective.

\section{Conclusions and Recommendations}

Bankruptcy law is much dependent on how borrowing and lending are related. A close, repeated, and less-than-arm's length borrowing-lending relationship rarely needs a formal bankruptcy proceeding since private workouts are more effective and efficient due to the low transaction cost setting. Thailand's lessons

\footnotetext{
5 This coincides with the Guide in Part I, I, A. Introduction, 3 stating "The Legislative Guide does not provide a single set of model solutions to address the issues central to an effective and efficient insolvency law, but assists the reader to evaluate different approaches available and to choose the one most suitable in the national or local context” (p. 2).

${ }^{6}$ For example, the authors found that the topic of conversion of reorganization to liquidation (in Part 2, IV. Reorganization, 14. Conversion to Liquidation, pp. 232-233), especially, "If conversion to liquidation requires a new application for commencement to be made, rather than relying upon the original application as the basis for the converted proceedings, it may lead to further delay and diminution of value” is useful for revising the Thai bankruptcy law since the failure of reorganization does not trigger liquidation and the new application for liquidation is required (Thavornyutikarn, 2006).

7 This corresponds with Guide to Enactment of the UNCITRAL Model Law on Cross-Border Insolvency, I. Purpose and the Origin of the Model Law, A. Purpose of the Model Law, 3.

${ }^{8}$ Foreign Business Act, B.E. 2542 (1999) requires any company with foreign shareholding of over 49 per cent to apply for the permission to do the business.
} 
reveal that incorporating reorganization provisions into the bankruptcy law of Thailand is unnecessary. It, also, benefits a limited number of large-scale debtors at the expense of creditors and existing relationships. Thus, adopting any international law to the national legislation must be thorough and must contemplate on the nature of the subject matter.

This caveat applies to the attempt of UNCITRAL for standardization of insolvency law and its cross-border provisions. The international unification must be traded off with economic efficiency in each country. UNCITRAL Legislative Guide and Model Law on Cross-Border Insolvency, nevertheless, are worth reviewing for appropriate and selective amendment of respective legislation that promotes economic efficiency, not the standardization of law.

\section{References}

Aghion, P., \& Bolton, P. (1992). An incomplete contracts' approach to bankruptcy and the financial structure of the firm. Review of Economic Studies, 59, 473-494.

Aghion, P., Hart, O. D., \& Moore, J. (1992). The economics of bankruptcy reform. Journal of Law, Economics, and Organization, 8, 523-546.

Akira, S. (1996). Capital accumulation in Thailand 1855-1985. Chiang Mai, Thailand: Silkworm Book.

Armour, J. (2001). The law and economics of corporate insolvency: A review. ESRC Centre for Business Research Working Paper, WP197.

Armour, J., \& Frisby, S. (2001). Rethinking receivership. Oxford Journal of Legal Studies, 21(1), 73-102.

Biais, B., \& Gollier, C. (1997). Trade credit and credit rationing. Review of Financial Studies, 10(4), 903-937.

Coase, R. (1960). The problem of social cost. Journal of Law \& Economics, 3, 1-44.

Dasri, T. (2000). Out-of-court corporate debt restructuring in Thailand. Paper presented at the International Conference on Systematic Resolution of Corporate and Bank Distress in Crisis-Affected East Asian Countries, Tokyo, Japan.

Eisenberg, T., \& Tagashira, S. (1996). Should we abolish chapter 11? The evidence from Japan. In J. S. Bhandari, \& L. A. Weiss (Eds.), Corporate bankruptcy: Economic and legal perspectives. Cambridge: Cambridge University Press.

Hoshi, T., Kashyap, A., \& Scharfstein, D. (1996). The role of banks in reducing the costs of financial distress in Japan. In J. S. Bhandari, \& L. A. Weiss (Eds.), Corporate bankruptcy: Economic and legal perspectives. Cambridge: Cambridge University Press.

IMF. (2000). Recovery from the Asian crisis and the role of IMF. Washington, D.C.: International Monetary Fund.

Kaufman, G. G., Krueger, T. H., \& Hunter, W. C. (1999). The Asian financial crisis: Origins, implications and solutions. Norwell, M.A.: Kluwer.

Locatelli, F. (2008). International trade and insolvency law: Is the UNCITRAL model law on cross-border insolvency an answer for Brazil?. Law and Business Review of the Americas, 14, 313-345.

Pongpaichit, P., \& Baker, C. (1995). Thailand: Economy and politics. Kuala Lumpur: Oxford University Press.

Rotjanasiributr, M. (2001). UNCITRAL model law on cross-border insolvency: Case study on the recognition of judgment or order of the foreign court (Unpublished LLM thesis, Chulalongkorn University, Bangkok, Thailand).

Sautner, Z., \& Vladimirov, V. (2012). Indirect bankruptcy costs and bankruptcy law. Retrieved from http://vladimir-vladimirov.net/

Sirtaine, S. (2011). Debt restructuring: Historical and international perspective. Retrieved from https://www.wbginvestmentclimate.org/advisory-services/regulatory-simplification/insolvency/upload/1_4_Corporate-debt-r estructuring-historical-perspective-2.pdf

Stiglitz, J. (2001). Bankrupcy laws: Basic economic principles. In S. Claessens, S. Djankov, \& A. Mody (Eds.), Resolution of financial distress: An international perspective on the design of bankruptcy laws. Washington, D. C.: World Bank Institute.

Sussangkarn, C., \& Nikomborirak, D. (2010). Thailand: Post-crisis rebalancing. Asian Economic Paper, 11(1), 1-26.

Thavornyutikarn, S. (2006). An economic analysis of bankruptcy law with particular reference to Thailand (Unpublished Ph.D. thesis, University of Leicester, UK).

UNCITRAL. (2005). Legislative guide on insolvency law. New York: United Nations.

White, M. J. (1998). Corporate bankruptcy. In P. Newman (Ed.), The new palgrave dictionary of economics and the laws. London: McMillan. 